дотримання розглянутих принципів у системі, оскільки всі вони $\epsilon$ взаємопов'язаними, взаємозумовленими та взаємодоповнювальними.

На наш погляд, потребують подальшого поглибленого дослідження окремі аспекти взаємовпливу загальнодидактичних принципів i принципів, які відображають саме специфіку мовної підготовки судноводія, а також питання ефективності їх реалізації в умовах кредитно-модульної системи організації навчального процесу в сучасному морському виші.

\title{
Література
}

$\begin{array}{ccccc}\text { 1. Алексеева Л. Е. Оптимизация } & \text { процесса } & \text { обучения } & \text { иноязычному } \\ \text { профессионально } & \text { ориентированному } & \text { общению } & \text { студентов } & \text { факультета }\end{array}$ международных отношений : дис. на соискание ученой степени канд. пед. наук : спец. : 13.00.02 «Теория и методика обучения и воспитания»/ Алексеева Лариса Евгеньевна. - СПб., 2002. - 313 с. 2. Вербицкий А. А. Компетентностный подход и теория контекстного обучения : Материалы к четвертому заседанию методологического семинара 16 ноября 2004 г./ А. А. Вербицкий. - М. : Исследовательский центр проблем качества подготовки специалистов, 2004. - 84 с. 3. Китайгородская Г. А. Интенсивное обучение иностранным языкам: теория и практика / Г.А. Китайгородская. - М. : Рус. яз., 1992. - 254 с. 4. Мнацаканьян А. Н. Пути реализации коммуникативного подхода к развитию умений и навыков иноязычной речи в курсе ESP / A. Н. Мнацаканьян // Пути взаимодействия языковых и профилирующих кафедр в неязыковом вузе : сб. научных статей / под ред. Ю. Б. Кузьменковой. - М.: ГУ ВШЭ, 2000. - Вып. 1. - С. 58-65. 5. Пассов Е. И. Обучение общению на иностранном языке : [учеб. пособ.] / Е. И. Пассова, Е. С. Кузнецова. - Серия «Методика обучения иностранным языкам», №15. - Воронеж, 2002. - 40 с. 6. Погостинский Ю. А. Принципы и элементы проблемного обучения / Ю. А. Погостинский // Проблемы и перспективы высшего гуманитарного образования в эпоху социальных реформ. Научн.-метод. межвуз. конф. (17-19 февраля 1998 г.) : тезисы докладов. - СПб. : Изд-во СПбГУП, 1998. С. 255-256. 7. Поляков О. Г. Английский язык для специальных целей : теория и практика : [учеб. пособ.] / О. Г. Поляков. - [2-е изд., стереотип.]. - М. : НВИ ТЕЗАУРУС, 2003. - 188 с. 8. Ситников А. П. Акмеологический тренинг : Теория. Методика. Психотехнологии / А. П. Ситников. - М. : Технологическая школа бизнеса, 1996. - 428 с. 9. Якиманская И. С. Личностно ориентированное обучение в современной школе / И. С. Якиманская. - М. : Сентябрь, 1996 - 96 с. 10. Rivers W. M. Interactive Language Teaching/ W. M. Rivers. - Cambridge : Cambridge University Press, 1993. - 228 c.

Галина Кушнір

\section{ВАЖЛИВІСТЬ МЕТОДІВ НАВЧАННЯ У ПРОЦЕСІ ЗАСВОСННЯ КРАЕЗНАВЧО-ТУРИСТИЧНИХ ЗНАНЬ СТУДЕНТАМИ ВИЩИХ НАВЧАЛЬНИХ ЗАКЛАДІВ}

Кушнір Г. Л. Важливість методів навчання у процесі засвоєння краєзнавчотуристичних знань студентами вищих навчальних закладів.

У статті розглядається важливість вибору методів навчання та оцінюється їх ефективність під час формування краєзнавчо-туристичних знань у студентів природничих спеціальностей. Аналізується майстерність викладача в навчальному 
процесі та вибір ним методів навчання відповідно до робочих програм, що призводить до високого рівня засвоєння краєзнавчо-туристичних знань студентами.

Ключові слова: методи навчання, краєзнавчо-туристичні знання, студент, класифікація методів навчання, вища освіта.

Кушнир Г. Л. Важность методов обучения в процессе усвоения краеведческотуристических знаний студентами высших учебных заведений.

В статье рассматривается важность выбора методов обучения и оценивается их эффективность при формировании краеведческо-туристических знаний у студентов естественных специальностей. Анализируется мастерство преподавателя в учебном процессе и выбор им методов обучения в соответствии с рабочими програмами, что приведет к высокому уровню усвоения краеведческо-туристических знаний студентами.

Ключевые слова: методы обучения, краеведческо-туристические знания, студент, классификация методов обучения, высшее образование.

Kushnir G. L. The importance of training methods for learning of local history and tourist knowledge by the university students.

The importance of the choice of teaching methods and their effectiveness in shaping of local lore and tourist knowledge of natural specialties' students is shown in the article. We analyze the importance of the skills of teachers in the classroom and their choice of teaching methods in accordance with the program, which will lead to a high level of assimilation of local lore and tourist knowledge of students.

Key words: teaching methods, local history and tourist knowledge, student, classification methods of teaching, higher education.

Вибір методів навчання $\epsilon$ достатньо нелегким завданням, осільки від правильності їх вибору й застосування залежить ефективність засвоєння знань студентами. У публікації автор характеризує методи навчання, які забезпечать високий рівень засвоєння краєзнавчо-туристичних знань. Узагальнюючи наукові підходи до класифікації методів навчання, зроблено спробу спроектувати їх у площину краєзнавчо-туристичних знань.

Питаннями класифікації методів навчання займалися Е. Голант, I. Лернер, I. Харламов, М. Скаткін, С. Петровський, Ю. Бабанський, та інші. У дослідженні автора цікавлять методи навчання, які допоможуть забезпечити високий рівень засвоєння краєзнавчо-туристичних знань студентами вищих навчальних закладах.

Mema cmammi- узагальнити розроблені підходи до поняття «методи навчання»; визначити які провідні методи навчання $\epsilon$ ефективними в процесі засвоєння краєзнавчо-туристичних знань студентами, які навчаються у вищих навчальних закладах на природничих спеціальностях.

Сучасна епоха - це епоха постійних соціальних перетворень та науковотехнічного прогресу, що зумовлює модернізацію системи вищої освіти. Наявні робочі програми та плани з багатьох дисциплін орієнтують вищі навчальні заклади на аудиторний тип проведення занять, що не надає змоги повною мірою застосовувати навчально-виховний потенціал, який полягає у взаємозв'язку 3 навколишнім середовищем, природою, господарством, тобто 3 усим тим, що дозволяє і перетворити на знання теоретичні факти, явища, процеси.

Одним із важливих напрямків на шляху удосконалення вищої освіти має стати підвищення інтересу студентів до вивчення свого краю. Ланкою, яка поєднує 
теоретичні щаблі навчання 3 повсякденним життям, природою, суспільством та господарством, є «Краєзнавство». Значення краєзнавства неоціненне у становленні особистості, оскільки під час його вивчення студенти вивчають історичне минуле $\mathrm{i}$ сучасне регіону свого проживання, ознайомлюються з природними, промисловими, господарськими особливостями рідного краю, що допомагає краще його пізнати, осягнути. «...Туризм і краєзнавство...дозволяють молоді на власні очі побачити красу рідної землі, ознайомитися з історією, культурою, традиціями свого народу, загартуватися як фізично, так і морально...» [10, с. 5].

На думку автора, під краєзнавчо-туристичними знаннями слід розуміти сукупність знань про рідний край, які отримують студенти під час туристичних походів i польових досліджень, необхідних для закріплення теоретичного краєзнавчого матеріалу, що актуалізує потреби особи в пізнанні природного, господарського і соціального місця свого існування, сприяючи формуванню іiі ціннісних орієнтацій і цілісних громадянських якостей.

Успіх краєзнавчої роботи в першу чергу залежить від викладача-краєзнавця. Він має визначити обсяг і зміст курсу «Краєзнавство», організувати студентську аудиторію до навчання, зацікавити їх та зацікавити предметом. Якщо викладач систематично не вивчатиме рідний край, зміни, які в ньому відбуваються, не поповнюватиме своєї скарбнички знань, то успіху краєзнавча робота не матиме. I навпаки, якщо викладач працюватиме над собою, інтелектуально збагачуватиметься, то він зможе плодотвірно донести свій предмет до аудиторії. Головним питанням процесу навчання $є$ : Як навчити? Які методи навчання краще застосувати, щоб досягти високої ефективності засвоєння знань?

Поняття методу навчання $є$ досить складним, що зумовлюється винятковою важкістю того процесу, який покликана відображати ця категорія.

Водночас попри значну кількість пропонованих визначень поняття «методу навчання», більшість дидактів уважають, що метод навчання $є$ способом організації навчальної та пізнавальної діяльності.

Нова філософська енциклопедія подає таке трактування терміна «метод»: «Метод - у найбільш широкому сенсі свідомий спосіб досягнення якого-небудь результату, здійснення певної діяльності, вирішення певних задач...» [4, с. 551]. Термін метод походить від грецького methodos, що означає дорога до чого-небудь, шлях. Поняття «науковий метод» можна охарактеризувати як цілеспрямований підхід, шлях, за допомогою якого досягається певна ціль, дещо пізнається або розв'язується. Метод становить комплекс різноманітних пізнавальних підходів i практичних операцій, направлених на здобуття наукових знань. У педагогіці під поняттям наукового методу мається на увазі система основних підходів і способів дослідження, які відповідають предмету і задачам педагогічної науки [9, с. 65].

Енциклопедія освіти, за редакцією В. Кременя, поняття «метод» подає так: метод - це серцевина процесу навчання, ланка, яка зв'язує запроектовану мету i кінцевий результат... 3 позиції сучасних педагогічних поглядів методи навчання характеризуються як багатогранне, багатовимірне, багатоякісне, поліфункціональне дидактичне явище.

Найбільш загальним можна вважати таке визначення: методи навчання - це впорядковані способи взаємозв'язаної діяльності вчителя і учнів, спрямовані на розв'язання навчально-виховних завдань [3, с. 492-493].

У структурі методів навчання виокремлюють прийоми. Прийом - це елемент методу, його складова частина, разова дія, окремий крок до реалізації методу або модифікації методу в тому випадку, коли метод невеликий за обсягом або простий 
за структурою [6, с. 470]. Розуміння краєзнавчих понять студентами, виявлення ними причинно-наслідкових зв'язків і встановленням асоціацій між географічними явищами та причинами їх виникнення в межах свого краю може досягатися за допомогою таких прийомів навчання:

1. Засвоєння краєзнавчо-туристичних знань відбувається у процесі безпосереднього вивчення краю під час польових практик, туристичних походів, екскурсій, причому екскурсії можуть бути у природу і на виробництво, здобуття знань у процесі спостереження за фенологічними явищами. Вивченням фенологічних явищ - характеру, інтенсивності і темпів розвитку, залежності і зв'язку, з'ясуванням причин, які їх зумовлюють, i закономірностей. Також спостереження можуть бути гідрологічними та кліматичними.

2. Студенти здобувають знання з літературних краєзнавчих джерел, довідників та картографічного матеріалу.

3. Отримання студентами краєзнавчо-туристичних знань про свій край iз лекційних занять викладачів.

4. Метод навчання має багато сторін і по кожній з них, методи навчання можна групувати в системи. У зв'язку з цим з'являється безліч класифікацій методів, у яких останні поєднуються на основі одного або ряду загальних ознак. Важливим $є$ питання яка ж класифікація доцільна при здобутті краєзнавчо-туристичних знань. Ефективною можна назвати ту, яка співзвучна 3 практикою вишівського навчання i слугує основою задля іiі раціоналізації.

Класифікація методів навчання - це впорядкована за певною ознакою їх система. Нині відомі десятки класифікацій методів навчання. Однак сучасна дидактична думка дозріла до розуміння того, що не слід намагатися встановити єдину i незмінну номенклатуру методів. Навчання - надзвичайно рухомий, діалектичний процес. Система методів повинна бути динамічною, щоб відображати цю рухомість, враховувати зміни, які постійно відбуваються у практиці застосування методів [6, с. 473-474].

Класифікація, що увійшла до історії педагогіки як традиційна (С. Петровський, Е. Голант) зділяє методи за пріоритетним джерелом передавання i характером сприймання інформації на три групи: словесні, наочні, практичні [1, с. 183].

Водночас, ознайомившись 3 різноманітними класифікаціями методів навчання, автор дійшов думки, що найбільш прийнятною для засвоєння краєзнавчотуристичних знань $є$ класифікація методів навчання за типом (характером) пізнавальної діяльності, запропонована I. Лернер та М. Скаткіним. Тип пізнавальної діяльності - це рівень самостійності пізнавальної діяльності, якого досягають, ті, хто навчається, працюючи за запропонованою вчителем схемою навчання... У поданій класифікації виокремлюють такі методи: пояснювально-ілюстративний (інформаційно-рецептивний); репродуктивний; проблемного викладу; частковопошуковий (еврестичний); дослідницький [6, с. 475].

Саме тому, на думку Ю. Бабанського, алгоритм оптимального вибору методів навчання має бути таким: викладача.

- Визначити, чи матеріал вивчатимуть самостійно, чи під керівництвом

- Визначити співвідношення репродуктивних і продуктивних методів. Якщо дозволяють умови, перевагу надавати продуктивним методам.

- Визначити співвідношення індуктивних i дедуктивних, аналітичних та синтетичних методів. 
- Визначити міру і спосіб поєднання словесних, наочних та практичних методів.

- Прийняти рішення про необхідність застосування методів стимулювання.

- Визначити час використання методів контролю і самоконтролю.

- Розроблення запасних варіантів на випадок відхилення реального процесу навчання від запланованого.

- Ефективність використання методів навчання у сучасній вищій школі значною мірою зумовлена оптимальною підтримкою засобів навчання, зокрема матеріально-технічних [1, с. 188].

У системі роботи з географії часто застосовують традиційні методи навчальної роботи в дещо видозміненому вигляді. 3-поміж них - бесіда, розповідь, лекція, дискусія, навчальна екскурсія. Використовують їх у поєднанні 3 географічними картами, картинами та іншими видами наочності, технічними засобами навчання.

Задля формування у студентів стійкої системи краєзнавчо-туристичних знань, уявлень, понять та активізації їх мисленнєвої діяльності необхідно залучати різноманітні джерела краєзнавчої інформації. Такі як, картографічні, літературні, статистичні дані, безпосереднє спостереження на місцевості, екскурсії. Використання краєзнавчого матеріалу надає змогу зрозуміти сутність явищ, процесів, подій, підтвердити наукові поняття фактами із природи і життя людей.

Систематизація краєзнавчих знань повинна базуватися на принципі систематичності та послідовності навчання, який передбачає формування знань студентів у певному порядку, де кожний елемент навчального матеріалу пов'язується 3 іншим. Виходячи 3 вказаного, актуальною проблемою виступає дослідження шляхів, змісту, форм і методів систематизації краєзнавчих знань студентів як важливої умови підвищення їх фахового рівня.

Практичний досвід краєзнавчої підготовки педагогічних фахівців характеризувався значним розривом між вимогами до педагогічного фахівця та обсягом необхідних знань і умінь (краєзнавчих, туристичних, музеєзнавчих тощо), які виявилися недостатніми з точки зору можливостей їх практичної реалізації [5, с. 79-80].

Методи навчання за типом пізнавальної діяльності використовував А. Сафіуллін, який уважав, що основна задача викладача в організації навчальної краєзнавчої роботи полягає в тому, щоб у кожному конкретному випадку виявити найбільш прийнятні методи і прийоми здійснення краєзнавчого підходу. Основними 3 них є:

1. Пояснювально-ілюстративний метод, який поєднує у собі словесні методи (розповідь, пояснення, робота 3 краєзнавчою літературою) 3 ілюстраціями різноманітних за змістом краєзнавчих джерел (карт, схем, діаграм, натуральних об'єктів тощо).

2. Частково-пошуковий метод, заснований на використанні краєзнавчих знань, життєвого і пізнавального досвіду... Конкретним виявом цього методу $є$ бесіда, яка залежно від дидактичних цілей ...може бути контрольною, еврестичною, повторювально-навчальною.

3. Робота з краєзнавчою літературою та джерелами.

4. Дослідницький метод як один із провідних способів організації пошукової діяльності. Він використовується: а) в організації метеорологічних, фенологічних і гідрологічних спостережень і в обробленні їх результатів (складання графіків, діаграм, схем тощо.); б) в описі природних і економічних фактів і явищ 
своєї місцевості; в) під час складання економіко-географічних характеристик місцевих підприємств; г) під час роботи над краєзнавчою літературою, довідниками й іншими джерелами краєзнавчого змісту; д) в організації і проведенні природознавчих і виробничих екскурсій. Усі ці методи і прийоми взаємопов'язані і практично використовуються в різноманітних поєднаннях [8, с. 70].

Репродуктивні методи навчання (репродукція - відтворення) - методи навчання, що грунтуються на репродуктивному характері мислення учнів. Репродуктивними виступають словесні, наочні і практичні методи (розповідь, лекція, бесіда, наочність, вправи, практичні завдання) у випадках, коли зміст навчального матеріалу: а) інформативний; б) $є$ описом способів практичних дій; в) $\epsilon$ принципово новим чи достатньо складним для самостійного засвоєння ... й подається у готовому вигляді [2, с. 286].

Основними методами вивчення свого краю треба вважати науково-дослідний, екскурсійний і письмово-анкетний. Саме за допомогою цих методів набираються відповідні методичні знання і вміння.

Розуміється, ми особливу увагу звертаємо на дослідний метод, - і як більш важливий і як більш складний, що вимагає і більш солідної підготовки.

Географо-краєзнавчі екскурсії - один із найбільш ефективних способів пізнання навколишньої природи i господарської діяльності населення, виховання...любові і бережливого ставлення до природи. На екскурсіях ті, хто навчається, більш свідомо засвоюють знання, оскільки явища і об'єкти вони бачать наочно і у взаємозв'язку. Крім того, на екскурсіях ...виконуючи певні практичні роботи, здобувають важливі вміння і навички [7, с. 22].

Спираючись на дослідження М. Русакова, автор дійшов висновку, що під час проведення польових практик з географічного краєзнавства доречно застосовувати такі методи:

1) стаціонарні систематичні спостереження окремих явищ природи (метеорологічні, гідрологічні, геоморфологічні, фенологічні);

2) тимчасові стаціонарні спостереження (мікрокліматичні);

3) епізодичні і періодичні екскурсії як програмні, так і спеціально краєзнавчі;

4) туристські походи і подорожі;

5) польові топографічні, геологічні, геоморфологічні, грунтові, фітогеографічні знімання.

Усі ці методи створюють належний ефект, якщо вони застосовуються в певній сукупності. Тому плануючи краєзнавчу роботу, потрібно також визначати методи здійснення завдання за кожним розділом плану.

Класифікація методів навчання є ключовою ланкою в педагогіці вищої школи. Узагальнюючи класифікації різних педагогів, автор дійшов висновку, що найбільш прийнятною для засвоєння краєзнавчо-туристичних знань є класифікація методів навчання за типом (характером) пізнавальної діяльності, запропонована I. Лернер та М. Скаткіним. Хоча задля досягнення педагогічної мети і відповідно до характеру засвоєння знань доцільно використовувати різноманітні методи навчання, які в своїй сукупності зумовлюють досягнення високого рівня засвоєння краєзнавчотуристичних знань у процесі підготовки студентів природничих спеціальностей.

\section{Література}

1. Біляковська О. О. Дидактика вищої школи: [навч. посіб.] О. О. Біляковська, І. Я. Мищишин, С. Б. Цюра. - Львів : ЛНУ імені Івана Франка, 2013. - 360 c. 2. Гончаренко С. У. Український педагогічний словник / С. У. Гончаренко. - К. : Либідь, 1997. - 374 с. 3. Енциклопедія освіти / Акад. пед. 
наук України; головний ред. В. Г. Кремень. - К. : Юрінком Інтер, 2008. - 1040 с. 4. Новая философская энциклопедия : В 4 т./ Ин-т философии РАН, Нац. общ.научн. фонд; Научно-ред. совет: предс. В. С. Степин, заместители предс. : А. А. Гусейнов, Г. Ю. Семигин, уч. секр. А. П. Огурцов. - М. : Мысль, 2010. T. II. - 634 с. 5. Обозний В. В. Краєзнавча освіта в системі професійної підготовки вчителя: дис. на здобуття наукового ступеня доктора пед. наук : 13.00 .04 / Обозний Василь Васильович. - К., 2001. - С. 79-80. 6. Подласый И. Т. Педагогика. Новый курс: [учебник для студ. пед. вузов]: В 2 кн. / И. Т. Подласый. - М. : Гуманит. изд. центр ВЛАДОС, 1999. - Кн. 1: Общие основы. Процесс обучения. - 576 с. 7. Прохорчик А. Ф. Организация и проведение комплексных краеведческих экскурсий / А.Ф. Прохорчик // Вопросы методики школьного географического краеведения : [сборник науч. трудов].- Минск: Минский пединститут им. А. М. Горького, 1982. - $\quad$ С. 22-29. 8. Сафиуллин А. 3. Географическое краеведение в общеобразовательной школе / А. 3. Сафиуллин. - М. : Просвещение, 1979. - 127 с. 9. Смирнов В. И. Общая педагогика: [учеб. пособ.]./ В. И. Смирнов. - [2-е изд., перераб., испр. и доп.]. - М. : Логос, 2002. - 304 с. 10. Тронько П. Краєзнавство як складова навчально-виховного процесу / Петро Тронько // Краєзнавство. - 2011. - №3. - С. 5-10.

Олександра Лисевич

\section{ФОРМУВАННЯ ТВОРЧОЇ КОМПЕТЕНТНОСТІ МАЙБУТНІХ УЧИТЕЛІВ ПОЧАТКОВИХ КЛАСІВ У ПРОЦЕСІ ЇХ ФАХОВОЇ ПІДГОТОВКИ}

Лисевич О. В. Формування творчої компетентності майбутніх учителів початкових класів у процесі їх фахової підготовки.

У статті розглядається проблема формування творчої компетентності майбутнього вчителя початкових класів, підходи та шляхи їі формування. Доведено необхідність створення умов, які сприяли б виявам творчої активності, створенню творчого мікроклімату, проблемно-пошукової атмосфери, необхідної для формування позитивних мотивів креативної діяльності. Обгрунтовано, що необхідними умовами для вияву творчості в педагогічній діяльності $є$ наявність творчих особистостей, творчого процесу, творчого середовища.

Ключові слова: творча компетентність, креативність, творча особистість, творчий потенціал, творчий процес, творче середовище, професіоналізм майбутніх учителів початкових класів.

Лисевич А. В. Формирование творческой компетентности будущих учителей начальных классов в процессе их профессиональной подготовки.

В статье рассматривается проблема формирования творческой компетентности будущего учителя начальных классов. Доказана необходимость создания условия, которые способствовали б проявлениям творческой активности, создать творческую атмосферу, необходимую для формирования позитивной мотивации, креативной деятельности. Обосновано, что необходимыми условиями для проявления творчества в педагогической деятельности является наличие творческих личностей, творческого процесса, творческой среды.

Ключевые слова: творческая компетентность, креативность, творческая личность, творческий потенциал, творческий процесс, творческая среда, профессионализм будущих учителей начальных классов. 